\title{
Steroidogenic acute regulatory protein mRNA expression in adrenal tumours
}

\author{
Simone Zenkert, Barbara Schubert, Martin Fassnacht, Felix Beuschlein ${ }^{1}$, Bruno Allolio and Martin Reincke ${ }^{1}$ \\ Schwerpunkt Endokrinologie, Department of Medicine, University of Würzburg, Germany and ${ }^{1}$ Schwerpunkt Endokrinologie, Department of Medicine, \\ University of Freiburg, Germany
}

(Correspondence should be addressed to M Reincke, Klinikum der Albert-Ludwigs-Universität, Abteilung Innere Medizin II, Schwerpunkt Endokrinologie, Hugstetterstr. 55, 79106 Freiburg, Germany; Email: reincke@mm21.ukl.uni-freiburg.de)

\begin{abstract}
The rate limiting step in steroidogenesis is cholesterol transport through the outer to the inner mitochondrial membrane and the cytochrome P450 side chain cleavage (P450scc) complex. The protein factor responsible for this transport, and as such necessary for regulating the acute production of steroids, has been identified and named the steroidogenic acute regulatory protein (StAR). We investigated the expression of StAR in functional and non-functional adrenal neoplasms and compared the expression with that of P450scc. Poly A RNA was extracted from normal adrenal glands (NAG, $n=5$ ), aldosterone producing adenomas (APA, $n=4)$, cortisol producing adenomas (CPA, $n=5$ ), adrenocortical carcinomas (ACC, $n=6$ ) and non-functional adenomas (NFA, $n=3$ ), electrophoresed through a $1 \%$ agarose gel, blotted and hybridised with a PCR-generated cDNA labelled with $\left[{ }^{32} \mathrm{P}\right] \mathrm{CTP}$. The blots were stripped and re-hybridised with a P450scc cDNA and a mouse $\beta$-actin probe. Compared with P450scc, StAR mRNA expression showed little variability in the magnitude of expression and did not correlate with the endocrine profiles (NAG: StAR $100 \pm 16 \%$, P450scc $100 \pm 14 \%$; APA: StAR $80 \pm 3 \%$, P450scc $94 \pm 13 \%$; CPA: StAR $71 \pm 10 \%$, P450scc $109 \pm 15 \%$; NFA: StAR $64 \pm 9.5 \%$, P450scc $18 \pm 5 \%$; means \pm s.E.m.). ACC expressed low levels of both genes probably as a result of dedifferentiation (StAR $29 \pm 9 \%$, P450scc $46 \pm 18 \%$ ). Incubation of the NCI-h295 tumour cell line with $10 \mathrm{nmol}$ ACTH and $10 \mu \mathrm{mol}$ forskolin induced an increase in the abundance of StAR and P450scc mRNA, demonstrating gene regulation by the cAMP protein kinase A pathway. Furthermore, we incubated the NCI-h295 tumour cell line with the adrenostatic compounds, aminoglutethimide and metyrapone. We could not detect an effect on the expression of StAR mRNA, whereas the expression of P450scc mRNA was significantly reduced. We conclude that, in contrast to P450scc, StAR seems to be evenly expressed in adrenocortical adenomas. Therefore, the endocrine activity of a given tumour cannot be explained by the abundance of StAR expression. In ACC, both StAR and $\mathrm{P} 450$ scc expression is low, explaining the relatively inefficient steroid production of these tumours.
\end{abstract}

European Journal of Endocrinology 142 294-299

\section{Introduction}

Cholesterol is the basic substance for all steroid hormones. It is stored in intracellular lipid droplets. For acute steroid biosynthesis, cholesterol has to be mobilised and delivered from these lipid droplets to the $\mathrm{P} 450$ side chain cleavage (P450scc) complex, which is associated with the inner mitochondrial membrane. This is achieved by transport of cholesterol through the outer to the inner mitochondrial membrane. This step is based upon the de novo synthesis of a cycloheximid sensitive protein $(1-4)$. The respective protein was first purified by Clark et al. from MA-10 mouse Leydig tumour cells and was called steroidogenic acute regulatory protein (StAR) (5). The definitive proof of the role of StAR in steroid biosynthesis was shown by Lin et al. (6). They showed that a mutation in the StAR gene causes congenital lipoid adrenal hyperplasia, a severe disease that is characterised by impaired synthesis of all adrenal and gonadal steroid hormones (7-9).

The structural StAR gene is encoded on chromosome $8 \mathrm{p} 11.2(2,10)$. StAR is synthesised as a $37 \mathrm{kDa}$ precursor protein with an N-terminal mitochondrial target sequence, and is transformed into a $30 \mathrm{kDa}$ protein during its transport into the mitochondria (2, 5, 11-13). The definite mechanism of the acute regulation of steroidogenesis by StAR is not known yet, but there are two proposed mechanisms: the association of StAR with the outer mitochondrial membrane facilitates the import of cholesterol, or the import of StAR to the inner mitochondrial membrane is concomitant with cholesterol transport. In both cases, the $37 \mathrm{kDa}$ precursor protein would be the active form and 
Table 1 Clinical data of the patients studied.

\begin{tabular}{lcccc}
\hline Tissue & No. & $\begin{array}{c}\text { Age } \\
\text { (years) }\end{array}$ & Sex & $\begin{array}{c}\text { Tumour size } \\
(\mathrm{cm})\end{array}$ \\
\hline Normal adrenal glands of brain-dead patients & 5 & $16-69$ & $2 \mathrm{~F} / 3 \mathrm{M}$ & \\
Aldosterone producing adenoma & 4 & $46-62$ & $2 \mathrm{~F} / 2 \mathrm{M}$ & $1.7-5.0$ \\
Cortisol producing adenoma & 5 & $31-49$ & $5 \mathrm{~F}$ & $1.8-7.0$ \\
Non-functional adenoma & 3 & $35-68$ & $3 \mathrm{~F}$ & $3.0-7.0$ \\
Adrenocortical carcinoma & 6 & $1-79$ & $4 \mathrm{~F} / 2 \mathrm{M}$ & $8.0-12.0$ \\
\hline
\end{tabular}

$\mathrm{F}=$ female, $\mathrm{M}=$ male

the cleavage of StAR to the $30 \mathrm{kDa}$ form would mean the inactivation of that protein $(2,14)$.

Because StAR represents the rate limiting event in acute steroidogenesis, StAR gene expression could be one of the factors influencing steroidogenesis in adrenocortical neoplasms. Recently, Liu et al. reported low StAR expression in non-functional tumours and high levels of gene expression in functional adrenocortical tumours (15). This is in contrast to our data presented here that StAR seems to be constitutively expressed in these tumours.

\section{Materials and methods}

\section{Tissues}

Adrenal tissue from 18 patients with adrenal disease and from 5 non-neoplastic adrenal glands was studied. Clinical data of these patients are shown in Table 1. The clinical and pathological diagnosis was made according to established criteria (16-18). Non-functional adenomas were found incidentally by computed tomography performed for unrelated reasons. These patients were asymptomatic, and endocrine function tests were normal (urinary free cortisol, serum cortisol after $1 \mathrm{mg}$ dexamethasone at $2300 \mathrm{~h}$, plasma renin, serum aldosterone). Non-neoplastic adult adrenals $(n=5)$ were obtained after organs were removed from brain-dead patients for transplantation. Adrenal tumour tissue was collected with the approval of the ethical committee of the University Hospital of Würzburg. We investigated aldosterone-producing adenomas (APA, $n=4$ ), cortisol producing adenomas (CPA, $n=5$ ), non-functional adenomas (NFA, $n=3$ ) and adrenocortical carcinomas (ACC, $n=6$ ).

Only central parts of tumours were used, avoiding necrotic areas and contamination with normal adjacent tissue. In addition, the integrity of the tissue was checked by light microscopy. The normal or neoplastic adrenal cortex was carefully dissected from the medulla with a scalpel using only the adrenal cortex for these experiments. The tissues were snap frozen and immediately stored at $-78^{\circ} \mathrm{C}$ until analysed.

\section{cDNA synthesis and purification of the StAR cDNA using reverse transcription-polymerase chain reaction (RT-PCR)}

Poly A mRNA of a normal adrenal gland was reverse transcribed to first strand complementary DNA (cDNA) by the primers shown in Table 2 (6) using the GeneAmp Reverse Transcriptase RNA PCR Kit (Perkin Elmer Cetus, Norwalk, CT, USA). For the reverse transcription, $40 \mathrm{ng}$ mRNA, $2 \mu \mathrm{l} 10 \times$ RTth-buffer, $2 \mu \mathrm{l} 10 \mathrm{mmol}$ $\mathrm{MnCl}_{2}$ and $1.6 \mu \mathrm{l} 10 \mathrm{mmol}$ NTPs, and $10 \mathrm{pmol}$ of the antisense primer, AS2, were incubated with $2 \mu \mathrm{l}$ RTth polymerase (Perkin Elmer Cetus) for $15 \mathrm{~min}$ at $70^{\circ} \mathrm{C}$. For the polymerase chain reaction, the reaction mix consisted of $64 \mu \mathrm{l} \mathrm{H} \mathrm{H}_{2} \mathrm{O}, 8 \mu \mathrm{l} 10 \times$ chelating buffer, $6 \mu \mathrm{l}$ $25 \mathrm{mmol} \mathrm{MgCl}_{2}$ and $10 \mathrm{pmol}$ of the sense primer, S1. Afterwards, denaturation at $95^{\circ} \mathrm{C}$ for $2 \mathrm{~min}$ was performed, followed by 30 cycles of amplification (each consisting of denaturation for $45 \mathrm{~s}$ at $94^{\circ} \mathrm{C}$, annealing for $30 \mathrm{~s}$ at $64^{\circ} \mathrm{C}$ and extension for $1 \mathrm{~min}$ at $72^{\circ} \mathrm{C}$ ). At the end, there was another extension for $7 \mathrm{~min}$ at $72^{\circ} \mathrm{C}$. The $672 \mathrm{bp} \mathrm{RT-PCR}$ product was reamplified using the primers S2 and AS2. The reaction mix contained the RT-PCR product, $10 \mu \mathrm{l} 10 \times$ buffer, $8 \mu \mathrm{l} 10 \mathrm{~mol} / \mathrm{l}$ NTPs, $30 \mathrm{pmol} \mathrm{S} 2$ and $30 \mathrm{pmol}$ AS2 primers, and $0.5 \mu \mathrm{l}$ Taq polymerase (Perkin Elmer). The amplification product had an expected length of $296 \mathrm{bp}$.

Table 2 Primers used for RT-PCR and PCR (7).

\begin{tabular}{ll}
\hline Primer & \multicolumn{1}{c}{ Sequence } \\
\hline Sense primer S1 (nt 66 to 84) & 5'-GCA GCA GCA GCG GCG GCA GCA G-3' \\
Sense primer S2 (nt 442 to 462) & 5'-GAC AAA GTG ATG AGT AAA GTG-3' \\
Antisense primer AS2 (nt 719 to 738) & 5'-TGT GGC CAT GCC AGC CAG CA-3' \\
\hline
\end{tabular}

$\mathrm{nt}=$ nucleotides. 
The plasmid for the P450scc cDNA was provided by Dr W L Miller (University of California, San Francisco, CA, USA) (19).

\section{Cell culture}

The NCI-h295 tumour cell line (20), provided by AF Gazdar (National Cancer Institute, NIH, Bethesda, MD, USA), was maintained in TIS medium (RPMI 1640 medium supplemented with transferrin $(0.1 \mathrm{mg} / \mathrm{ml})$, insulin $(5 \mathrm{mg} / \mathrm{ml})$ and selenium $(5.2 \mathrm{mg} / \mathrm{ml}))$ as described by Fassnacht et al. (21). The cells were grown in $75 \mathrm{~cm}^{2}$ flasks (approx. 1.0 million cells $/ \mathrm{ml}$ ), incubated for $48 \mathrm{~h}$ with forskolin $\left(10^{-5} \mathrm{~mol} / \mathrm{l}\right.$; Sigma, Deisenhofen, Germany), adrenocorticotrophin (ACTH) $\left(10^{-8} \mathrm{~mol} / \mathrm{l}\right.$; Ciba-Geigy, Wehr, Germany), aminoglutethimide $(3 \times$ $10^{-4} \mathrm{~mol} / \mathrm{l}$, Sigma) and metyrapone $\left(3 \times 10^{-4} \mathrm{~mol} / \mathrm{l}\right.$, Sigma). Each experiment was performed in triplicate.

\section{RNA extraction and Northern analysis}

Polyadenylated RNA (tissue) and total RNA (cell culture) were isolated using commercial kits (Qiagen, Hilden, Germany). Three micrograms mRNA or $25 \mu \mathrm{g}$ total RNA were electrophoresed on a 1\% agarose-formaldehyde gel. The integrity of the major RNA species was examined under UV light to ensure consistency between lanes. The RNA was blotted by capillary transfer onto a nylon membrane (Qiabrane Nylone membrane, Qiagen) and crosslinked by exposure to UV radiation. Prehybridisation was carried out at $68^{\circ} \mathrm{C}$ with Quickhyb solution (Stratagene, Heidelberg, Germany) for $1 \mathrm{~h}$.

Hybridisation was performed in the same buffer at $68^{\circ} \mathrm{C}$ for $1 \mathrm{~h}$ using the StAR cDNA labelled with $\left[\alpha^{32}-\mathrm{P}\right] \mathrm{dCTP}$ (Amersham Buchler, Braunschweig, Germany; Random Primed Labelling kit, Boehringer, Mannheim, Germany). Unincorporated nucleotides were separated from radiolabelled DNA probes by Nuc Trap purification columns (Stratagene). After washing at $60^{\circ} \mathrm{C}$ twice for $15 \mathrm{~min}$ in $1 \times \mathrm{SSC}$ and for $15 \mathrm{~min}$ in $0.5 \times$ SSC (each containing $0.1 \%$ SDS), the blots were exposed to a Kodak X-OMAT-DS film (Kodak, Fernwald, Germany) at $-78{ }^{\circ} \mathrm{C}$ with intensifying screens. Blots were stripped with $0.1 \times \mathrm{SSC}$ and rehybridised with cDNA probes for $\mathrm{P} 450 \mathrm{scc}$, and for standardisation with a mouse $\beta$-actin cDNA probe.

The relative intensity of the hybridisation signals was quantified by scanning densitometry. Autoradiographic images were digitalised with a video camera and a Macintosh PowerMac 7100 computer-based image analysis system using the IMAGE program $(\mathrm{NIH})$. For statistical analysis, the $1.6 \mathrm{~kb}$ StAR major transcript and the $2.0 \mathrm{~kb} \mathrm{P} 450 \mathrm{scc}$ transcript were selected. The results were expressed as a percentage of normal adrenal glands $(=100 \%)$ or control cells $(=100 \%)$ after normalisation for $\beta$-actin expression. Correlation was determined by linear regression analysis and expressed as Pearson's correlation coefficient.

\section{Results}

StAR mRNA was detected in all investigated adrenocortical tissues. Normal and neoplastic adrenocortical tissue expressed three StAR mRNA transcripts, one major band of $1.6 \mathrm{~kb}$ and two minor bands of 3.4 and $4.5 \mathrm{~kb}$ which were visible after prolonged exposure (data not shown).

There was only little variability in the magnitude of StAR mRNA expression in adrenocortical adenomas (APA: $80 \pm 3 \%$; CPA: $71 \pm 10 \%$; NFA: $64 \pm 9.5 \%$ vs $100 \pm 16 \%$ in normal adrenals; means \pm s.E.M.), whereas adrenocortical carcinomas expressed low StAR mRNA levels $(29 \pm 9 \%)$ (Fig. 1A and B). P450scc mRNA expression, however, correlated with the endocrine activity of the adenomas, being higher in the aldosterone and cortisol producing adenomas than in non-functional adenomas (Fig. 1C). No close correlation was found between StAR mRNA and P450scc mRNA in adrenocortical tumours $\left(\mathrm{R}^{2}=0.24\right)$ (Fig. 1D).

Stimulation of the protein kinase A pathway with ACTH and forskolin induced a 1.2-fold and 1.5-fold increase, respectively, in the abundance of StAR mRNA expression in the NCI-h295 cell line (Fig. 2). The incubation of NCI-h295 tumour cells with the adrenostatic compounds, aminoglutethimide and metyrapone, almost completely blocked steroidogenesis (aminoglutethimide: cortisol $1.3 \pm 1 \%$, dehydroepiandrosterone sulphate (DHEA-S) $8.2 \pm 1 \%$, aldosterone $6.1 \pm$ $1 \%$; metyrapone: cortisol $3 \pm 1 \%$, DHEA-S $11.5 \pm 2 \%$, aldosterone $9.9 \pm 1 \%$ vs $100 \%$ in control cells). This resulted in a reduced expression of P450scc mRNA (control cells: $100 \pm 3.9 \%$; aminoglutethimide: $68 \pm$ $0.9 \%$; metyrapone: $69 \pm 6.9 \%$ ). There was no demonstrable effect on the expression of StAR mRNA (control cells: $100 \pm 8 \%$; aminoglutethimide: $94 \pm 2 \%$; metyrapone: $107 \pm 11.5 \%)$.

\section{Discussion}

In this study, we investigated the expression and regulation of StAR mRNA in adrenocortical tumours and in the steroid producing NCI-h295 adrenocortical carcinoma cell line. Our data show that StAR mRNA expression is present in most of the adrenocortical tumour tissues analysed and shows little variability between tumours of different endocrine activity. StAR mRNA is also present in non-functional adenomas which express no or little P450scc mRNA.

Recent studies have implicated StAR as an essential component of the acute responses of steroidogenic cells to trophic hormones. StAR expression is restricted to steroidogenic cells, where it is rapidly induced by trophic hormone in a manner that correlates with the acute stimulation of steroidogenesis $(5,11,22,23)$. Definite proof for the essential role of StAR in steroidogenesis came from studies of patients with lipoid congenital adrenal hyperplasia, a congenital disorder characterised 

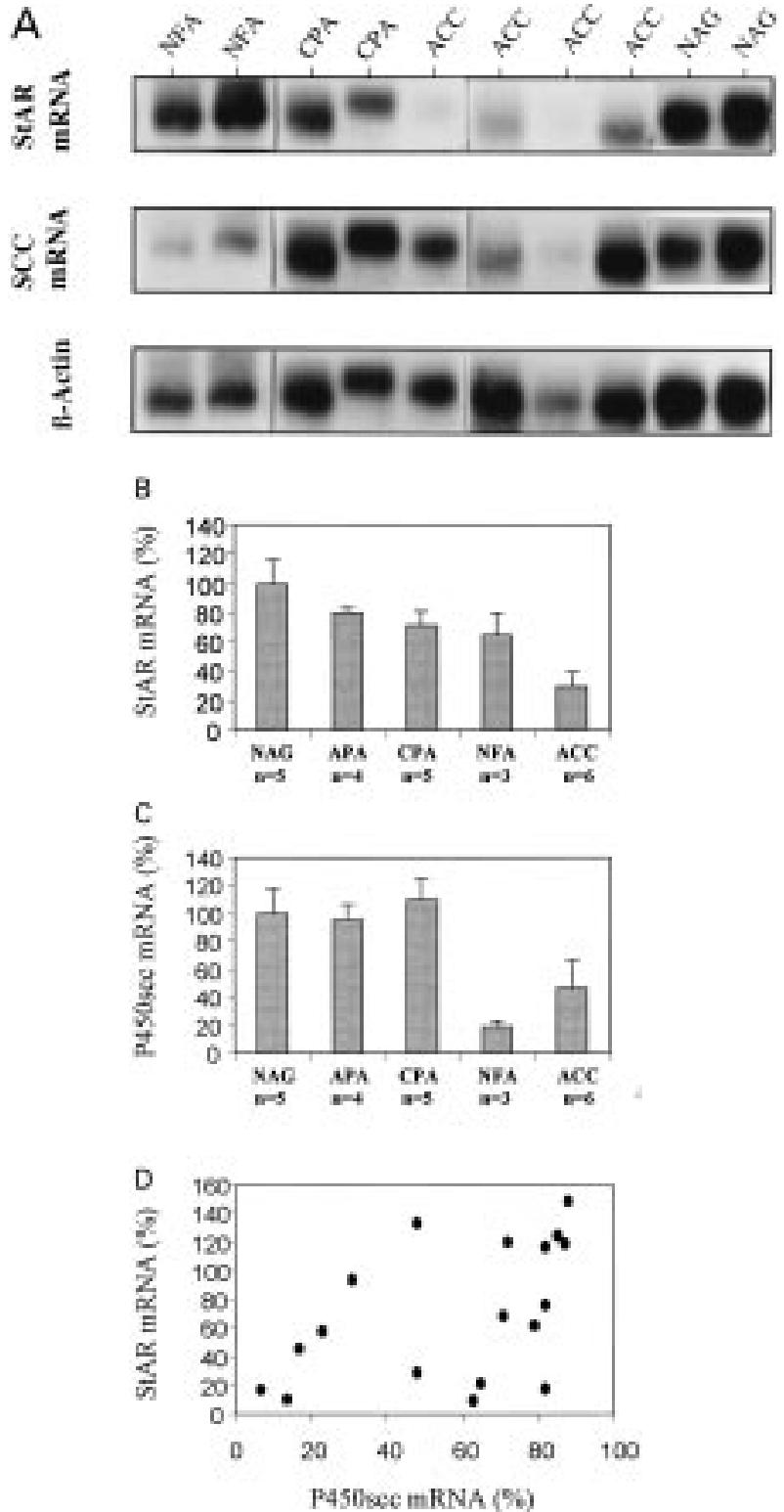

Figure 1 (A) Northern blot of StAR mRNA and P450scc mRNA expression in human non-neoplastic adrenals and in adrenal tumours. The blots were stripped and rehybridised with a mouse $\beta$-actin cDNA (bottom). The panel shows the $1.6 \mathrm{~kb}$ StAR mRNA main transcript and the $2.0 \mathrm{~kb}$ P450scc mRNA transcript.

(B) StAR mRNA expression assessed by Northern blot in normal adrenal glands (NAG), aldosterone producing adenomas (APA), cortisol producing adenomas (CPA), non-functional adenomas (NFA) and adrenocortical carcinomas (ACC). All values are expressed as a percentage of normal adrenal glands $(=100 \%)$ and shown as means \pm S.E.M. (C) Expression of P450scc mRNA expressed as a percentage of normal adrenal glands $(=100 \%)$ and shown as means \pm S.E.M. (D) Correlation between StAR mRNA and P450scc mRNA in adrenocortical tumours $\left(R^{2}=0.24\right)$.

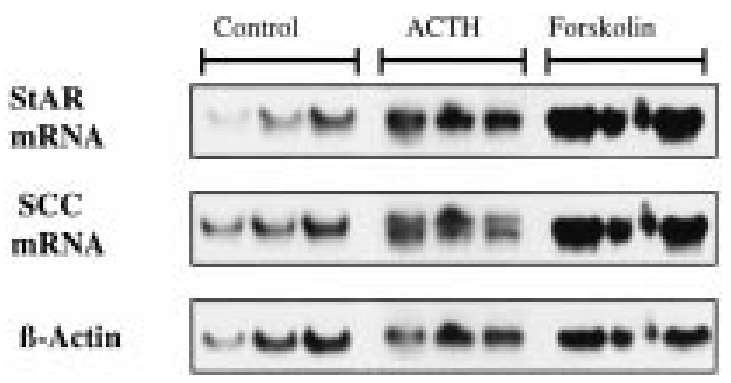

Figure 2 Northern blot of StAR mRNA and P450scc mRNA expression in NCl-h295 tumour cells. The figure shows the effects of incubation with ACTH or forskolin on StAR mRNA and P450scc mRNA expression. The blots were stripped and rehybridised with a mouse $\beta$-actin cDNA (bottom).

by severe impairment of steroid biosynthesis in the adrenal glands and gonads that is manifested both in utero and postnatally. Analysis of 3 patients with this disorder revealed mutations in the StAR gene that preclude the expression of functional StAR protein (6). In a more recent paper on 15 patients with lipoid congenital adrenal hyperplasia from 10 different countries, it was shown that the phenotype of this disease is the result of two separate events, an initial genetic loss of steroidogenesis that is dependent on StAR, and a subsequent loss of steroidogenesis that is independent of the protein due to cellular damage from accumulation of cholesterol ester (24).

We showed recently that adrenocortical tumours express P450 steroid enzymes dependent on the endocrine profile and the cellular differentiation of the tumours (25). For example, P450scc is upregulated in functional adrenal tumours, but is low in nonsecreting adrenal tumours. Interestingly, the two main receptors of the adrenal cortex, the ACTH receptor and the angiotensin II type 1 receptor, follow a similar pattern of expression in adrenal tumours, with high levels of expression in functional adenomas, and low levels of gene expression in non-functional adenomas $(26,27)$. StAR mRNA expression in adrenocortical tumours was recently studied by Liu et al. (15). In their study they reported a good correlation between StAR and P450scc mRNA levels in normal and pathological adrenal tissues. This is in agreement with our data, with the exception of non-functional adenomas which did express StAR but not P450scc mRNA in our series. The difference between our results and the study of Liu et al. may be related to the fact that nonfunctional adenomas are heterogeneous as a group. Whereas some non-functional adenomas lack P450 enzymes and are truly non-functional, other tumours express $\mathrm{P} 450$ enzymes and may produce adrenal steroids in small amounts not sufficient to cause clinically apparent disease or to be detected by adrenal function tests. It is, therefore, our experience that P450scc mRNA correlates better with the endocrine 
activity of the tumour tissue than does StAR mRNA. The difference in tumour-specific regulation of StAR and P450scc cannot be explained at present. It could be due to differences in the transcriptional regulation of both genes. So far, the promoter of the StAR gene has been only partially characterised $(23,28,29)$. For basal gene transcription both promoters require binding sites of steroidogenic factor 1 , and gene expression of both StAR and P450scc is increased by stimulation of the protein kinase A pathway. More recently, it was shown that the orphan nuclear receptor, DAX-1, binds to both promoters and suppresses gene transcription and steroidogenesis $(30,31)$.

In cell culture experiments of primary adrenocortical cells, Liu et al. showed homonymous upregulation of StAR and P450scc mRNA by ACTH and cAMP (15). We used the carcinoma cell line NCI-h295, which may serve as a pluripotent cellular model of the functional tumorous adrenal cortex. Our experiments demonstrate that stimulation of the protein kinase A pathway with ACTH or forskolin increased the gene expression of P450scc and StAR in a similar way. However, the fold stimulation induced by forskolin and by ACTH was weaker in the NCI cell line than that reported with primary adrenal cell cultures, probably due to low expression of ACTH receptor binding sites and an impaired adenylyl cyclase system. Our results are also at variance with the data of Rainey et al. (32) who showed that forskolin but not ACTH induced a strong increase in P450scc mRNA in the NCI-h295 cell line. These discrepancies could be due to differences in the experimental design (for example incubation for $24 \mathrm{~h}$ instead of $48 \mathrm{~h}$, as in our experiments) or to differences in the NCI-h295 cell line used for the experiments. We have previously noted that the endocrine profile and the pattern of $\mathrm{P} 450$ enzyme expression of the NCI-h295 cell line changes during long-term culture conditions due to selection of different clones. With regard to P450scc expression, the NCI strain used in our experiments is known to respond well to stimulation by ACTH (21).

The incubation of the NCI-h295 tumour cells with the adrenostatic compounds, aminoglutethimide and metyrapone, resulted in suppression of glucocorticoid, mineralocorticoid and androgen secretion, paralleled by reduced expression of P450scc mRNA, suggesting presumably a positive feedback of steroid secretion on gene expression which is inhibited by adrenostatic treatment. Fassnacht et al. described a similar, but more profound effect on ACTH receptor mRNA expression (21). The expression of StAR mRNA was not changed by incubation with either aminoglutethimide or metyrapone in our experiments. This argues against a similar steroid-mediated feedback on StAR gene transcription.

In summary, we show that StAR mRNA expression is evenly expressed in benign functional and nonfunctional adrenocortical tumours. We conclude that the functional state of these tumours cannot be explained by the relative abundance of StAR mRNA expression.

\section{Acknowledgements}

This work was supported by the Wilhelm-SanderStiftung, München.

\section{References}

1 Clark BJ \& Stocco DM. Expression of the steroidogenic acute regulatory (StAR) protein: a novel LH-induced mitochondrial protein required for the acute regulation of steroidogenesis in mouse Leydig tumor cells. Endocrine Research 199521 243-257.

2 Stocco DM. A StAR search: implications in controlling steroidogenesis. Biology of Reproduction 199756 328-336.

3 Clark BJ, Pezzi V, Stocco DM \& Rainey WE. The steroidogenic acute regulatory protein is induced by angiotensin II and K+ in H295R adrenocortical cells. Molecular and Cellular Endocrinology 1995 $115215-219$.

4 Selvaraj N, Israeli D \& Ansterdam A. Partial sequencing of the rat steroidogenic acute regulatory protein message from immortalized granulosa cells: regulation by gonadotropins and isoproterenol. Molecular and Cellular Endocrinology 1996123 171-177.

5 Clark BJ, Wells J, King SR \& Stocco DM. The purification, cloning, and expression of a novel luteinizing hormone-induced mitochondrial protein in MA-10 mouse Leydig tumor cells. American Society for Biochemistry and Molecular Biology 19941128314 28322.

6 Lin D, Sugawara T, Strauss JF 3rd, Clark BJ, Stocco DM, Saenger P, Rogol A \& Miller WL. Role of steroidogenic acute regulatory protein in adrenal and gonadal steroidogenesis. Science 1995267 1828-1830.

7 Sakai Y, Yanase T, Okabe Y, Hara T, Waterman MR, Takayanagi R, Haji M \& Nawata H. No mutation in cytochrome P450scc in a patient with congenital lipoid adrenal hyperplasia. Journal of Clinical Endocrinology and Metabolism 199479 1198-1201.

8 Fujieda K, Tajima T, Nakae J, Sageshima S, Tachibana K, Suwa S, Sugawara T \& Strauss JF 3rd. Spontaneous puberty in 46,XX subjects with congenital lipoid adrenal hyperplasia. Journal of Clinical Investigation 199799 1265-1271.

9 Okuyama S, Nishi N, Onishi S, Itoh S, Ishii O, Miyanaka H, Fujita $\mathrm{K} \&$ Ichikawa $\mathrm{O}$. A novel splicing junction mutation in the gene for the steroidogenic acute regulatory protein causes congenital adrenal hyperplasia. Journal of Clinical Endocrinology and Metabolism 199783 2337-2342.

10 Sugawara T, Holt JA, Driscoll D, Strauss JF 3rd, Lin D, Miller WL, Patterson D, Clancy KP, Hart IM, Clark BJ \& Stocco DM. Human steroidogenic acute regulatory protein: functional activity in COS-1 cells, tissue-specific expression, and mapping of the structural gene to 8 p11.2 and a pseudogene to chromosome 13. Biochemistry $1995924778-4782$.

11 King SR, Ronen-Fuhrmann T, Timberg R, Clark BJ, Orly J \& Stocco DM. Steroid production after in vitro transcription, translation, and mitochondrial processing of protein products of complementary deoxyribonucleic acid for steroidogenic acute regulatory protein. Endocrinology 1995136 5165-5175.

12 Nishikawa T, Sasano H, Omura M \& Suemtatsu S. Regulation of expression of the steroidogenic acute regulatory (StAR) protein by ACTH in bovine fasciculata cells. Biochemical and Biophysical Research Communications 1996223 12-18.

13 Kirikaidou M, McAllister JM, Sugawara T \& Strauss JF 3rd. Expression of steroidogenic acute regulatory protein (StAR) in the human ovary. Journal of Clinical Endocrinology and Metabolism $1996814122-4128$ 
14 Eastbrook RW \& Rainey WE. Twinkle, twinkle little StAR, how we wonder what you are. Proceedings of the National Academy of Sciences of the USA $19969313552-13554$.

15 Liu J, Heikkliä P, Kahri AI \& Voutilainen RC. Expression of the steroidogenic acute regulatory protein mRNA in adrenal tumors and cultured cells. Journal of Endocrinology 199615043 49.

16 Weiss LM. Comparative histologic study of 43 metastasing and nonmetastasing adrenocortical tumors. Journal of Pathology 1984 8 163-169.

17 Baxter JD \& Tyrrel JB. The adrenal cortex. In Endocrinology and Metabolism, edn 2, pp 511-692. Eds P Felig, JD Baxter, AE Broadus \& LA Frohmann. New York: McGraw-Hill, 1986.

18 Orth DN, Kovacs WJ \& DeBold CR. The adrenal cortex. In Williams Textbook of Endocrinology, edn 8, pp 489-621. Eds JD Wison \& DW Foster. Philadelphia: Saunders, 1992.

19 Chung B, Matteson KJ, Voutilainen R, Mohandas TK \& Miller WL. Human cholesterol side-chain cleavage enzyme P450scc: cDNA cloning, assignment of the gene to chromosome 15, and expression in the placenta. Proceedings of the National Academy of Sciences of the USA $1986838962-8966$.

20 Gazdar AF, Oie HK, Shackleton CH, Chen TR, Triche TJ, Myers CE, Chrousos GP, Brennan MF, Stein CA \& La Rocca RV. Establishment and characterization of a human adrenocortical carcinoma cell line that expresses multiple pathways of steroid biosynthesis. Cancer Research 199050 5488-5496.

21 Fassnacht M, Beuschlein F, Vay S, Mora P, Allolio B \& Reincke M. Aminoglutethimide suppresses adrenocorticotropin receptor expression in the NCI-h295 adrenocortical tumor cell line. Journal of Endocrinology 1998159 35-42.

22 Fleury A, Cloutier M, Ducharme L, Lefebvre A, LeHoux J \& LeHoux J-G. Adrenocorticotropin regulates the level of the steroidogenic acute regulatory protein mRNA in hamster adrenals. Endocrine Research 199622 515-520.

23 Caron KM, Ikeda Y, Soo SC, Stocco DM, Parker KLN \& Clark BJ. Characterization of the promotor region of the mouse gene encoding the steroidogenic acute regulatory protein. Molecular Endocrinology 199711 138-147.

24 Bose HS, Sugawara T, Strauss JF 3rd \& Miller WL. The pathophysiology and genetics of congenital lipoid adrenal hyperplasia. International Congenital Lipoid Adrenal Hyperplasia Consortium. New England Journal of Medicine 1996335 18701878.

25 Reincke M, Beuschlein B, Latronico AC, Arlt W, Chrousos GP \& Allolio B. Expression of adrenocorticotrophic hormone receptor mRNA in human adrenocortical neoplasms: correlation with P450scc expression. Clinical Endocrinology 199746 619-626.

26 Reincke M, Beuschlein F, Menig G, Hofmockel G, Arlt W, Lehmann R, Karl M \& Allolio B. Localization and expression of adrenocorticotropic hormone receptor in normal and neoplastic human adrenal cortex. Journal of Endocrinology 1998156 415-423.

27 Reincke M, Schubert B, Beuschlein F, Fassnacht M, Arlt W \& Allolio B. Angiotensin II type 1 and ACTH receptor expression in functional adrenocortical tumors. 80th Annual Meeting of the Endocrine Society, Minneapolis, 1998. Program and Abstracts, $\mathrm{P} 2-376$.

28 Sugawara T, Holt JA, Marianthi K \& Strauss JF. Steroidogenic factor 1-dependent promotor activity of the human steroidogenic acute regulatory protein (StAR) gene. Biochemistry 1996 35 9052-9059.

29 Sugawara T, Kiriakidou M, McAllister JM, Kallen CB \& Strauss JF. Multiple steroidogenic factor 1 binding elements in the human steroidogenic acute regulatory protein gene $5^{\prime}$-flanking region are required for maximal promoter activity and cyclic AMP responsiveness. Biochemistry $1997367249-7255$.

30 Lalli E, Bardoni B, Zazopoulos E, Wurtz J-M, Strom TM, Moras D \& Sassone-Corsi P. A transcriptional silencing domain in DAX-1 whose mutation causes adrenal hypoplasia congenita. Molecular Endocrinology 199711 1950-1960.

31 Zazopoulos E, Lalli E, Stocco DM \& Sassone-Corsi P. DNA binding and transcriptional repression by DAX-1 blocks steroidogenesis. Nature $1997390311-315$.

32 Rainey WE, Bird IM \& Mason JI. The NCI-H295 cell line: a pluripotent model for human adrenocortical studies. Molecular and Cellular Endocrinology 1994100 45-50.

Received 24 March 1999

Accepted 18 November 1999 